\title{
Characteristic Analysis of Resonant Filter
}

\author{
Yoshio Mitsutake Member (Matsushita Electric Works, Ltd.) \\ Katsuhiro Hirata Senior Member (Osaka University) \\ Manabu Nakata Member (Matsushita Electric Works, Ltd.) \\ Yoshiyuki Ishihara Member (Doshisha University) \\ Toshiyuki Todaka Member (Doshisha University)
}

Keywords: resonant filter, moment method, scattering parameter

Usually, the resonant filter is composed of several resonators which is made of dielectric and metal, and is applied to high frequency B.P.F. (Band Pass Filter). Although a resonant filter has simple structure, it is very difficult to obtain the optimal geometry experimentally, because it's filter characteristic is greatly influenced by the material and the structure.

This paper presents an analysis method for the high frequency resonant filter using moment method.

Fig. 1 shows the analyzed model. Fig. 2 shows the comparison between measured and computed results of $S_{21}$ characteristics. showing the validity of the computation. As shown, the validity of the computation was confirmed.

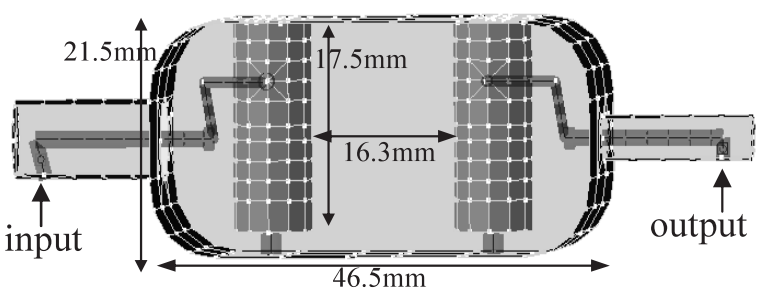

Fig. 1. Analyzed model

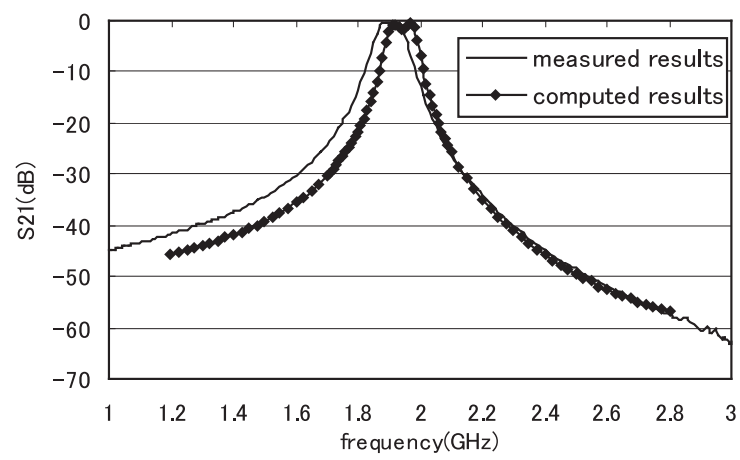

Fig. 2. Comparisons between measured and computed results of $S_{21}$ characteristics
Fig. 3 and Fig. 4 show the influence of the design parameters of the filter on $S_{21}$. It is found that resonant frequency is influenced by the resonator length and the bandwidth is also influenced by the distance between two resonators. The effectiveness of the computation is verified through other complicated model.

As the results, it was confirmed that the method of moment (MOM) is quite useful in applying to design a resonant filter.

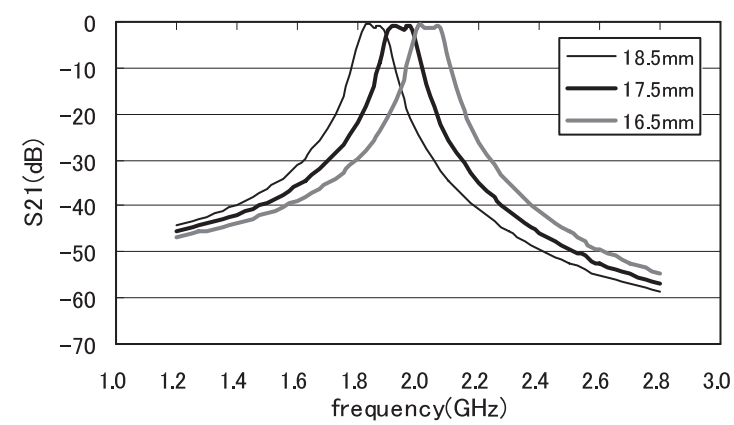

Fig. 3. Influence of the resonator length on $\mathrm{S}_{21}$ characteristics.

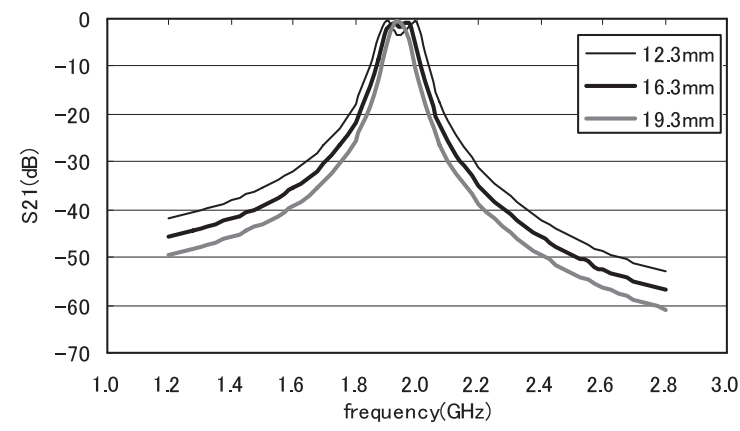

Fig. 4. Influence of distance between resonators on $S_{21}$ characteristics 


\title{
共振器結合形フィルタの特性解析
}

\author{
正 員 光武 義雄 ${ }^{*}$ 上級会員 平田 勝弘 ${ }^{* *}$ \\ 正員 中田学* 正員石原 好之*** \\ 正 員 戸高 敏之块
}

\section{Characteristic Analysis of Resonant Filter}

Yoshio Mitsutake*, Member, Katsuhiro Hirata**, Senior Member,

Manabu Nakata*, Member, Ishihara Yoshiyuki***, Member, Toshiyuki Todaka***, Member

Usually, the resonant filter is composed of several resonators which is made of dielectric and metal, and is applied to high frequency B.P.F. (Band Pass Filter). Although a resonant filter has simple structure, it is very difficult to obtain the optimal geometry experimentally, because its filter characteristic is greatly influenced by the material and the structure. This paper presents an analysis method for the high frequency resonant filter by using the method of moment (MOM). The computed characteristics of the resonant filter are in good agreement with the measured ones. Furthermore, the influences of design parameters of the filter on the characteristics are investigated.

キーワード : 共振フィルタ, モーメント法, 散乱パラメータ

Keywords: resonant filter, method of moment, scattering parameter

\section{1. まえがき}

近年, 携带電話など無線通信機器の高周波化に伴い, $\mathrm{GHz}$ 帯を越える高周波フィルタの設計開発が盛んに行われてい る。共振器結合形フィルタは, 電子部品を用いず, 誘電体・ 筐体等から構成されるものであり, BPF（Band Pass Filter） などに応用されている。共振器結合形フィルタは, 構造は 単純であるが，その伝送特性は材質及び形状により決定さ れるため, 仕様要求を満足するための詳細設計は経験的, 実 験的に行っているのが現状である (1) (3)。

本稿では， $2 \mathrm{GHz}$ で用いる共振型フィルタを取り上げ, モーメント法による伝送特性解析を行い, 実測結果と比較す ることにより解析值の妥当性を明らかにすると共に, 形状・ 材質が伝送特性へ与える影響要因について明らかにする。

\footnotetext{
* 松下電工 (株) 先行技術開発研究所

干 571-8686 大阪府門真市門真 1048

Advanced Technologies Development Laboratory, Matsushita Electric Works, Ltd.

1048, Kadoma, Osaka 571-8686

** 大阪大学 大学院 工学研究科

干 565-0871＼cjkstart吹田市山田丘 2-1

Department of Adaptive Machine Systems, Osaka University

Yamadaoka, 2-1, Suita 565-0871

*** 同志社大学 工学部 電気工学科

干 610-0394 京田辺市多々羅都谷 1-3

Faculty of Engineering, Doshisha University

1-3, Tatara miyakodani, Kyotanabe 610-0394
}

\section{2. モーメント法}

モーメント法 (Method of Moment) は，アンテナ解析や 金属による散乱問題へ有効に応用されており，境界上に仮 定した未知電磁流を求める手法である。任意の金属導体表 面を $N$ 個のサーフェイスパッチに分割し，それぞれのパッ チにピーク值 $I_{n}$ で正弦波状の電流（展開関数 $J_{n}$ ) が割り当 てられる。 $I_{n}$ と $J_{n} に よ り$, 金属導体表面に流れる未知の電 流分布 $J_{S}$ は (1) 式に展開される。

$$
J_{S}=\sum_{n=1}^{N} I_{n} J_{n}
$$

電流 $I_{m}$ が流れている金属導体表面パッチに着目すると, 金属導体の境界条件などより，(2) 式が成り立つ。

$$
Z_{m 1} \cdot I_{1}+\cdots+Z_{m m} \cdot I_{m}+\cdots+Z_{m N} \cdot I_{N}=0 \cdots \cdots
$$

ここで, $Z_{m n}$ は相互インピーダンスで $n$ 番目の電流 $I_{n}$ か ら番目の導体に照射される電界 $E_{b}$ に相当する。電圧源 $V$ が接続されたパッチでは, 電源から電界が強制的に印加さ れ, 電源が接続されたパッチ上では, 自己の電流と他のパッ チ電流によって誘起する電界の総和の接線成分は, 電源に よって印加される電界に一致する。これらの条件より連立 方程式が定式化でき, 電流分布 $J_{S}$ を得る。また, 電流分布 $J_{S}$ より，(3)，(4) 式により電界を求める。

$$
E=-j \omega A+\frac{1}{j \omega k^{2}} \nabla \nabla \cdot A
$$




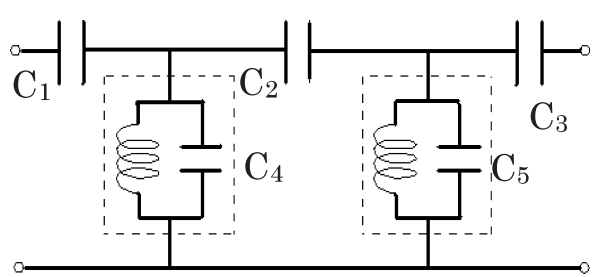

図 1 C 結合型 2 段共振器結合フィルタの等価回路 Fig. 1. Equivalent circuit of $\mathrm{C}$ coupling 2 stage resonant filter.

$$
A=\frac{\mu}{4 \pi} \int_{S} J_{s} \frac{e^{-j k x}}{r} d s \ldots \ldots \ldots \ldots \ldots \ldots \ldots \ldots \ldots \ldots \ldots \ldots \ldots \ldots
$$

$r$ : 観測点と電流分布 $J_{S}$ との距離, $k$ : 波数

\section{3. 共振器結合形 BPF の基本構造と動作}

共振周波数の等しい任意の構造の共振器の電磁界結合に より，BPFを構成することができる。電磁界結合形の BPF には，C 結合，L 結合，誘導磁界による $\mathrm{M}$ 結合などがある。 フィルタの伝達特性に影響を及ぼす要因としては，例えば 図 1 に示すような $\mathrm{C}$ 結合型の場合，共振器の共振周波数お よび，段間結合容量，入出力結合容量が通過域の带域幅と リプルに影響を与える。また，減衰域における減衰特性に ついては共振器の段数を増やすと急峻な減衰特性を得るこ とができる。しかしながら GHz 带上になると LC 共振器 では損失が大きくなり，Q值が低下するため，同軸共振器 や空洞共振器が用いられるようになる。このような共振器 においては簡易な構造の場合，理論的に伝達特性の解析を 行うことが可能であるが，実際に用いられる半同軸共振器 などの場合には解析が困難となり，詳細形状の検討を行う 場合には，試行錯誤的に調整を行う必要があるのが現状で ある。更に，減衰特性を改善するための多段型のフィル夕 の設計においては検討すべきパラメータの組み合わせが増 大するため，調整が非常に困難となる ${ }^{(4)}$ 。

\section{2 段共振器結合形 BPF 解析モデル}

図 2 に 2 段共振器結合形 BPF のモデルを示す。本モデ ルは，遮断導波路に円筒の半同軸共振器を 2 つ挿入した 2 段の共振器結合 BPF であり，図 1 に示されるような等価 回路に置換することが容易ではなく，数值解析による伝送 特性解析が非常に有効となるモデルである。図 3 にモーメ ント法の解析モデルを示す。点はノードを，線は要素を示 し，金属表面にパッチ要素，信号線にワイヤ要素を用いてい る。ノード数 776 , パッチ要素数 829 , ワイヤ要素数 45 で ある。各要素には以下に示す材質の導電率を物性值として 与えて解析を行う。筐体は縦 $21.5 \mathrm{~mm}$, 横 $46.5 \mathrm{~mm}$, 高さ $20.5 \mathrm{~mm}$ ，材質はアルミニウムで導電率は $3.64 \times 10^{7} / \mathrm{S} / \mathrm{m}$ である。また, 共振器は高さ $17.5 \mathrm{~mm}$ であり, 高さ $8.3 \mathrm{~mm}$ までは内部が空洞で，内径 $4.0 \mathrm{~mm}$ ，外径 $8.0 \mathrm{~mm}$ の円筒状 の導体である。材質は真鍮で銀めっきを施しており，導電率

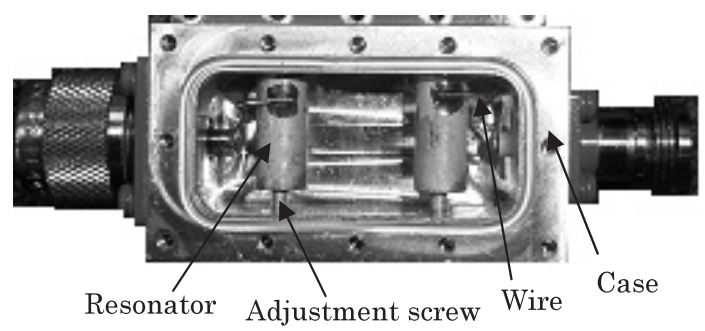

図 $2 \mathrm{BPF}$ の構造

Fig. 2. Structure of the BPF.

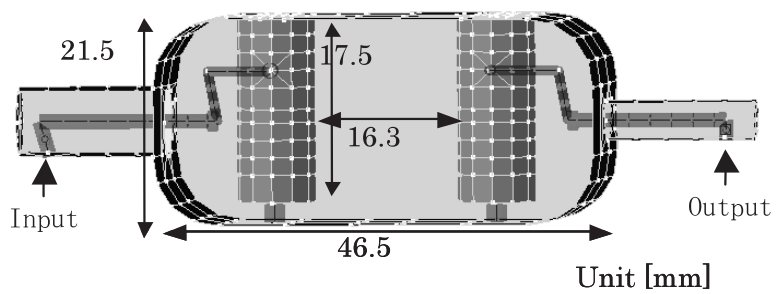

(a) Whole model.

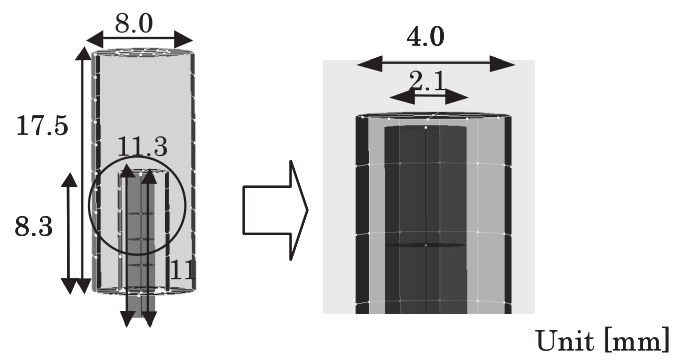

(b) Enlarged inside view of the resonator.

図 3 解析モデル

Fig. 3. Analyzed model.

は $6.17 \times 10^{7} \mathrm{~S} / \mathrm{m}$ である。また, 共振器間の距離は $16.3 \mathrm{~mm}$ である。入力および出力部の信号線の材質は銅で導電率は $5.81 \times 10^{7} \mathrm{~S} / \mathrm{m}$ である。2 段 BPF モデルのフィル夕仕様 は, 中心周波数 $1.9 \mathrm{GHz}$, 挿入損失 $-1.0 \mathrm{~dB}$ 以下，阻止特 性 $-45 \mathrm{~dB}$ 以上であり，そのフィル夕特性はバタワース曲 線（最大平坦曲線）により調整されている。伝送特性は, 共振器の形状・共振器間の距離, 調整ネジ長などにより大 きな影響を受ける。また，共振器内部の拡大図に示すよう に，円筒中には直径 $2.1 \mathrm{~mm}$ のネジが挿入されており，調 整ネジのケースからの突出量によりその微調整を行ってい る。フィルタ特性調整後のネジ長は $11.0 \mathrm{~mm}$, 材質はアル ミニゥムで導電率は $3.64 \times 10^{7} \mathrm{~S} / \mathrm{m}$ である。

\section{5. 解析結果の実機検証}

$\mathrm{BPF}$ の重要な特性の一つに入力から出力への電力の透過 量を表す $\mathrm{S}$ パラメータ $\mathrm{S}_{21}$ がある。これは入力信号の振幅 をVin, 出力信号の振幅をVout とすると Vout/Vin で表さ れ，入力から出力への伝送特性を表すパラメータである。 $\mathrm{S}_{21}$ について, 本解析モデルにおけるネットワークアナラ イザHP8753 による 2 段 BPF モデルの実測結果と, モー 


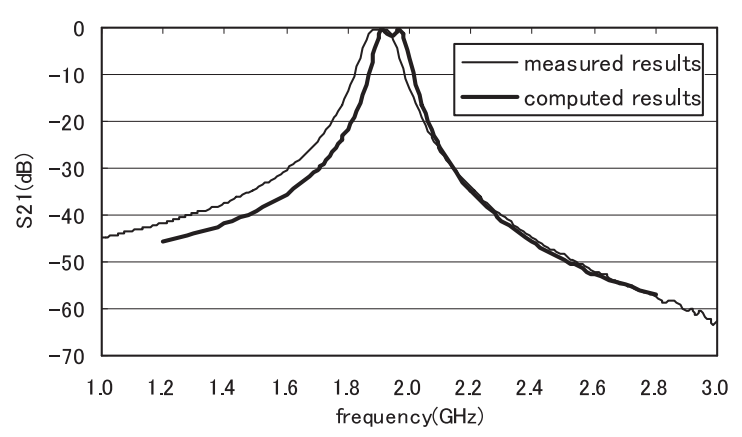

図 4 実測值と解析值の比較

Fig. 4. Comparison between measured and computed results.

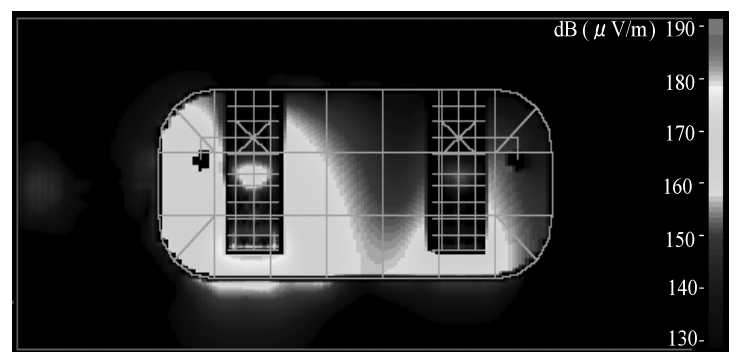

(a) Stopband (1.8 GHz)

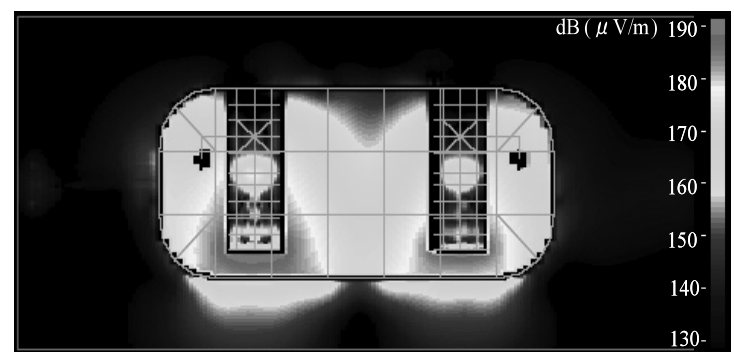

(b) Passband (1.9 GHz)

図 5 電界強度分布

Fig. 5. Electric field intensity distribution.

メント法による解析結果について比較検証する。解析にお ける入力部は正弦波の $2 \mathrm{~V}$ とし, 出力部は $50 \Omega$ で終端し ている。解析值と実測值との比較を図 4 に示す。実測值 は，1.9 GHz を中心として約 $80 \mathrm{MHz}$ の通過帯域を持ち， $1.0 \mathrm{GHz}, 2.4 \mathrm{GHz}$ にて $-45 \mathrm{~dB}$ の減衰を示している。挿入 損失は $-0.6 \mathrm{~dB}$ である。また，解析值は $1.94 \mathrm{GHz}$ を中心 として約 $90 \mathrm{MHz}$ の通過特性を持ち，1.2 GHz，2.4 GHzに て $-45 \mathrm{~dB}$ の減衰を示している。挿入損失は $-1.2 \mathrm{~dB}$ であ る。また, 阻止域, 通過域における電界強度と磁界強度の 最大時における分布を，図 5, 図 6 に示す。電界強度分布に おいて，阻止域では，一次側の電界分布が二次側に伝わっ ておらず，一次側と二次側が電磁界として結合していない。 一方, 通過域では, 一次側の電界分布が二次側に伝わって いることが分かる。

実測值と解析值を比較すると, 中心周波数は $40 \mathrm{MHz}$ 高 く, 通過帯域は $10 \mathrm{MHz}$ 大きい值となっている。若干の差 は見られるものの, 通過特性, 減衰特性とも, 比較的良く一

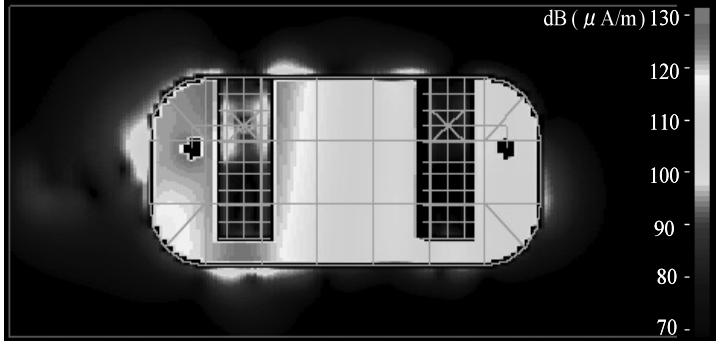

(a) Stopband $(1.8 \mathrm{GHz})$

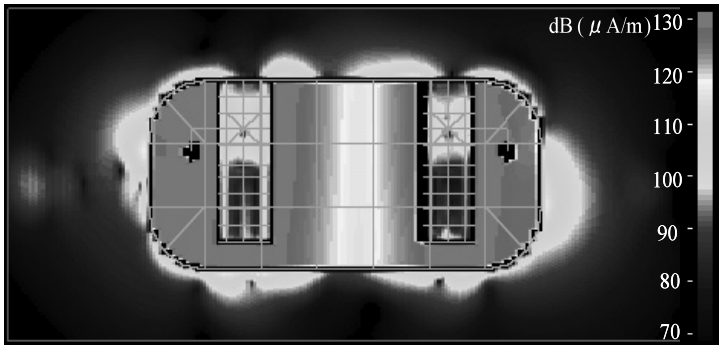

(b) Passband (1.9 GHz)

図 6 磁界強度分布

Fig. 6. Magnetic field intensity distribution.

致しており, 本解析モデルにおけるモーメント法の有用性を 示している。また差が生じた原因として, 解析におけるモ デル寸法と実際のモデル寸法が異なっていることが考えら れ, 調整ネジ長を $0.3 \mathrm{~mm}$ 大きく, 共振器間距離を $1.2 \mathrm{~mm}$ 小さくすると共振周波数, 通過帯域は一致する。このよう に, 形状寸法は特性に大きな影響を与え, 次章において各 形状要因が特性へ与える影響を検討する。

\section{6. フィルタ形状が伝送特性へ与える影響}

〈6・1〉 共振器長の影響 周波数調整ねじ長 $11 \mathrm{~mm}$ お よび, 調整ねじと共振器間の空隙 $0.3 \mathrm{~mm}$ は変化させず, 共 振器長のみを $17.5 \mathrm{~mm} よ り \pm 1 \mathrm{~mm}$ 変化させた場合の $\mathrm{S}_{21}$ 特性への影響をモーメント法解析により求めた結果を図 7 に示す。通過帯域の中心周波数はおよそ $\pm 100 \mathrm{MHz}$ 変化す るが, 通過帯域は $60 \mathrm{MHz}$ から大きな変化は見られないこ とが分かる。また，共振器長によるインピーダンス特性の 変化を図 8 に示す。共振器長 $17.5 \mathrm{~mm}, 16.5 \mathrm{~mm}$ において, それぞれ低域側の共振点が $1.94 \mathrm{GHz}, 2.05 \mathrm{GHz}$ となって おり, 共振器長が短くなると, 共振器と周波数調整ねじ間 の容量が小さくなり, 共振器の共振周波数が高くなること を示している。また, 共振器長の変化に関しては段間結合 については変化が小さく, 通過帯域幅にはほぼ変化が無い ことを示している。

$\langle 6 \cdot 2\rangle$ 調整ネジ・共振器間距離の影響共振器長は $17.5 \mathrm{~mm}$ とし, 調整ネジ長を変化させたときの $\mathrm{S}_{21}$ 特性に 与える影響を図 9 に示す。調整ネジ長を $1 \mathrm{~mm}$ 短くすると, 通過帯域の中心周波数はおよそ $125 \mathrm{MHz}$ 高くなるが, 通過 帯域幅には大きな変化は見られない。これは, 共振器長に よる影響と同様に，調整ネジ長を短くすると，ネジと共振 器内部との対向面積が小さくなり, 共振器部の容量が小さ 


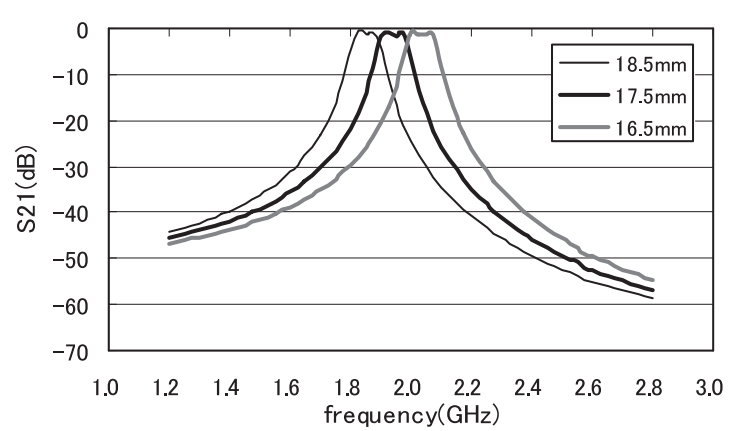

図 7 共振器長の $S_{21}$ 特性への影響

Fig. 7. Influence of the resonator length on $S_{21}$ characteristics.

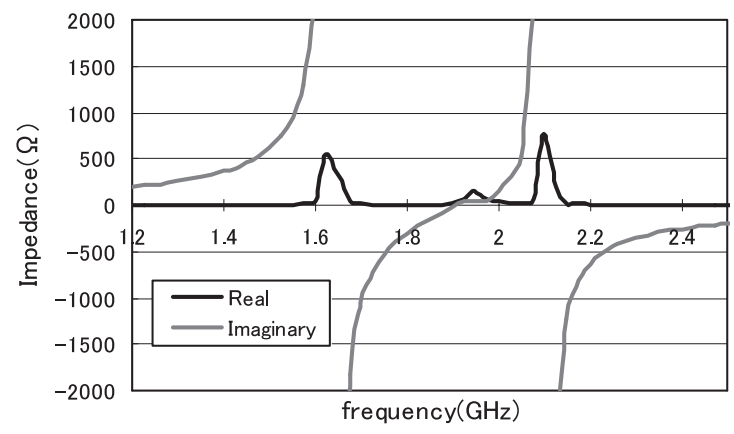

(a) Length of resonator: $17.5 \mathrm{~mm}$

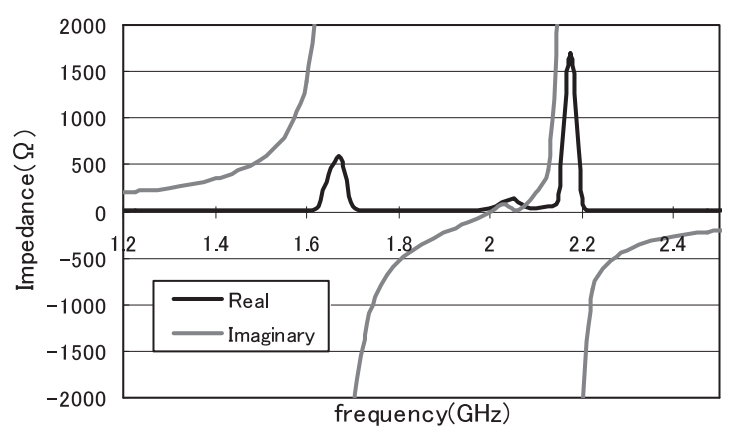

(b) Length of resonator: $16.5 \mathrm{~mm}$

図 8 共振器長のインピーダンス特性への影響

Fig. 8. Influecne of the resonator length on Impedance characteristics.

くなるため，共振周波数が高くなることを示している。 次に, 共振器長は $17.5 \mathrm{~mm}$, 調整ねじ長を $11 \mathrm{~mm}$ とし, 共振器間距離を変化させたときの $\mathrm{S}_{21}$ 特性に与える影響を 図 10 に示す。共振器間距離を $16.3 \mathrm{~mm}$ より $\pm 3 \mathrm{~m}$ 変化さ せると, 通過帯域は㧍よそ干 $25 \mathrm{MHz}$ 変化するが, 共振周 波数に大きな変化はない。また，共振器間距離を大きくす ると通過帯域内でのリプルが大きくなり，チェビシェフ形 の特性となることが確認できる。このことは, 共振器距離 を小さくすることにより，段間結合容量が大きくなり，こ れにより通過帯域が広がり，リプルが大きくなることを示 している。

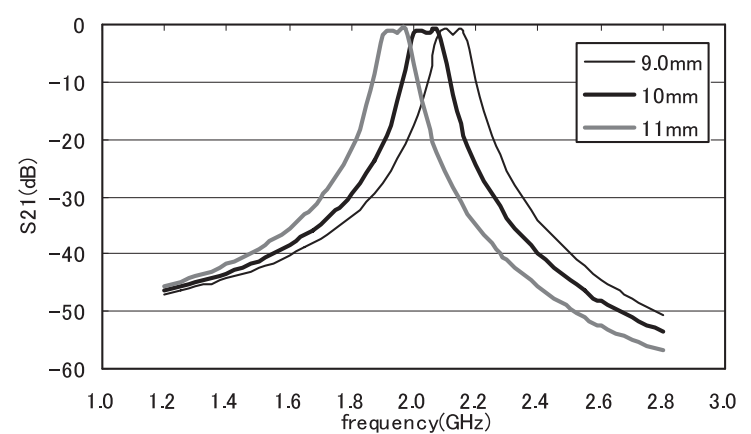

図 9 調整ネジ長の $S_{21}$ 特性への影響

Fig. 9. Influence of the length of adjustment screw on $\mathrm{S}_{21}$ characteristics.



図 10 共振器間距離による $S_{21}$ 特性への影響

Fig. 10. Influence of the length of distance between resonators on $\mathrm{S}_{21}$ characteristics.

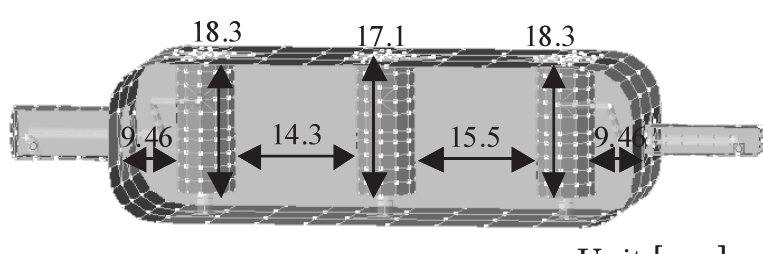

Unit $[\mathrm{mm}]$

図 113 段 BPF 解析モデル

Fig. 11. Analyzed model of 3 stage BPF.

\section{3 段共振器結合形 BPF 解析モデル}

図 11 に 3 段共振器結合形 BPF のモーメント法解析モデ ルを示す。これは前述の 2 段共振器結合形 BPF より, 段数 を一つ増やし 3 段共振器結合形 BPF としたモデルで, 各部 材質は 2 段共振器結合型モデルと同様である。共振器長, ねじ長, 共振器間距離など, 調整要因となる寸法パラメー 夕を設定した。ノード数 1052 , パッチ要素数 1133 , ワイ ヤ要素数 50 である。筐体は縦 $21.5 \mathrm{~mm}$, 横 $66.5 \mathrm{~mm}$, 高 さ $20.5 \mathrm{~mm}$ である。また, 共振器は左から高さ $18.3 \mathrm{~mm}$, $17.1 \mathrm{~mm}, 18.3 \mathrm{~mm}$ であり, それぞれ高さ $8.3 \mathrm{~mm}$ までは内 部が空洞で, 内径 $4.0 \mathrm{~mm}$, 外径 $8.0 \mathrm{~mm}$ の円筒状であり, 円筒中には直径 $2.1 \mathrm{~mm}$, 長さ $11 \mathrm{~mm}$ のネジが挿入されて いる。共振器間距離は, $14.4 \mathrm{~mm}, 15.5 \mathrm{~mm}$ である。フィ ル夕仕様は，2段モデルと同様，中心周波数 $1.9 \mathrm{GHz}$ ，挿 


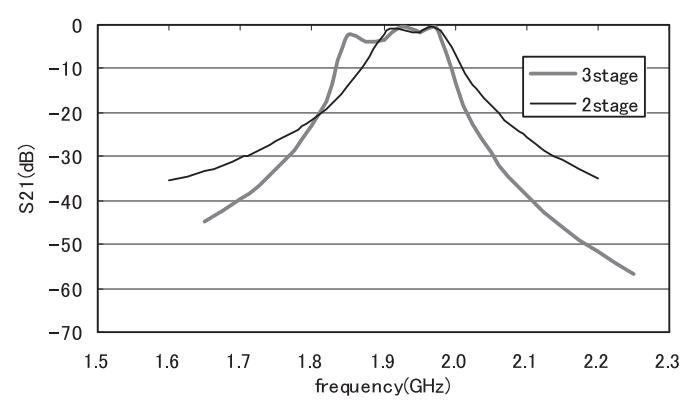

困 12 段数の $\mathrm{S}_{21}$ 特性への影響

Fig. 12. Influence of the resonator stage on $\mathrm{S}_{21}$ characteristics.

入損失 $-1.0 \mathrm{~dB}$ 以下，阻止特性 $-45 \mathrm{~dB}$ 以上として調整を 行っている。

\section{3 段共振器結合形 BPF 解析結果}

解析に扔ける入力部は 2 段 BPF モデルと同様，正弦波の $2 \mathrm{~V}$ とし, 出力部は $50 \Omega$ で終端している。3 段 BPF モデ ルに扔ける $\mathrm{S}_{21}$ 特性の解析結果を 2 段 BPF モデルと比較し て図 12 に示す。 3 段 BPF モデルは，1.9 GHz を中心とし た $125 \mathrm{MHz}$ 程度の通過特性を持ち，1.6 GHz，2.1 GHzに て $-45 \mathrm{~dB}$ の減衰を示している。挿入損失は $-2.6 \mathrm{~dB}$ であ る。段数を増やしたことにより, 減衰特性が向上し, 挿入 損失が増加していることが確認できる。ここで示した 3 段 BPF モデルに打いては, パラメータ検討等の最適化を行っ ていない状態であり，さらなる形状の検討により抻入損失 の向上は可能であると考えられる。

そこで, 次に, 各形状要因が特性へ与える影響について 検討を行う。モーメント法解析により, 中心共振器の長さ を変化させたときの $S_{21}$ 特性を図 13 に示す。中心共振器 の共振器長を $17.1 \mathrm{~mm}$ より $\pm 0.7 \mathrm{~mm}$ 変化させると, 中心 周波数は打よそ $\pm 25 \mathrm{MHz}$ 変化する。また，通過带域も招 よそ $\pm 50 \mathrm{MHz}$ 変化していることが分かる。左共振器と中 心共振器間の距離を変化させたときの $S_{21}$ 特性を図 14 に 示す。共振器間距離を $14.3 \mathrm{~mm}$ より $\pm 3.2 \mathrm{~mm}$ 変化させる と, 通過带域は打よそ干 $25 \mathrm{MHz}$ 変化するが, 共振周波数に 大きな変化はないことが分かる。次に，阻止域，通過域に 打ける磁界強度の最大時に扔ける分布を図 15 に示す。磁 界強度分布に抢いて，阻止域では，一次側の磁界分布が二 次側に伝わっておらず，通過域では，一次側の磁界分布が 二次側に伝わり，電磁界として結合している様子が確認で きる。

これら解析結果より，3段 BPF モデルの形状が特性に与 える影響は, 共振器長の変化により, 共振周波数, 通過帯 域が共に変動するなど，より複雑化していることが分かる。 さらに考慮すべきパラメータの組み合わせも増大するため, その特性調整は困難であり，モーメント法解析を用い，その フィル夕設計を行うことは非常に有用であると考えられる。

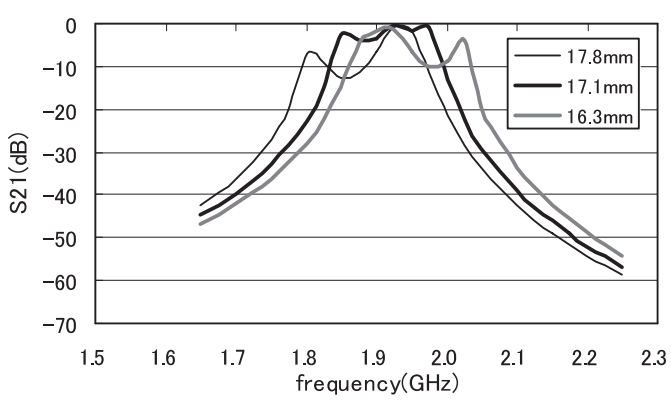

図 13 共振器長による $\mathrm{S}_{21}$ 特性への影響

Fig. 13. Influence of the resonator length on $S_{21}$ characteristics.

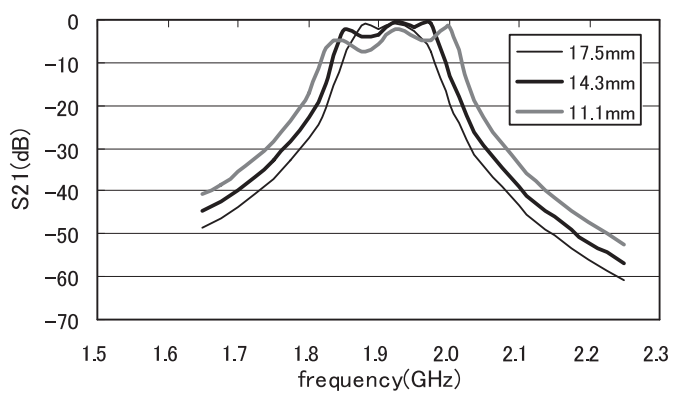

図 14 共振器間距離の $S_{21}$ 特性への影響

Fig. 14. Influence of the length of distance between resonators on $\mathrm{S}_{21}$ characteristics.

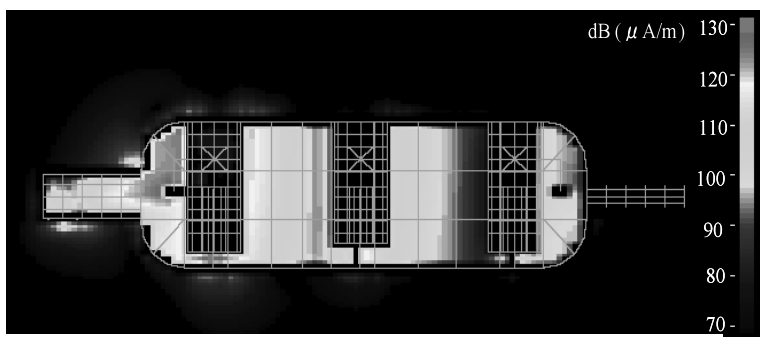

(a) Stopband (1.7 GHz)

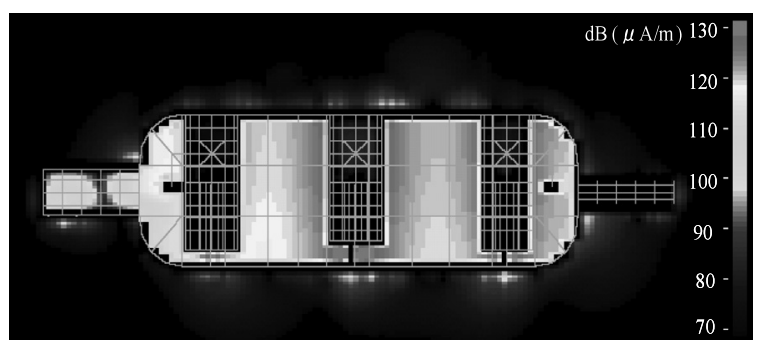

(b) Passband (1.9 GHz)

図 15 磁界強度分布

Fig. 15. Magnetic field distributions.

\section{9. まとめ}

2 段共振器結合形BPF モデルにおいて, 実測結果と, モー メント法による数值解析結果との比較を行ったところ, 通 過特性，阻止特性ともに良い一致を示した。また，共振器 結合形フィルタの各形状要因が特性へ与える影響を検討す 
るため，2段 BPF モデルにおいて，共振器長・調整ネジ ・ 共振器間距離を変化させたときの伝送特性解析を行った。

その結果, 共振器長・調整ネジは主として共振周波数に 影響を与え, 共振器間幅は主として通過帯域, 通過帯域内の リプルに影響を与えることが確認できた。次に，3段 BPF モデルにおいて，モーメント法による特性解析を行ったと ころ，2 段 BPF モデルと比べ，減衰特性は向上し，挿入損 失は増加するという結果が得られた。また， 3 段 BPF モデ ルの形状パラメータが特性に与える影響は，より複雑化し ていることを確認し, 多段型のフィルタにおいては検討す ベきパラメータの組み合わせが増大してしまうことと併せ て，より複雑化するフィルタ設計にモーメント法解析を適 用することが非常に有効であることを確認した。

今後は，モーメント法を用いたフィルタ特性解析と種々 の最適化手法と組み合わせることにより，仕様を満足する 共振器結合形フィルタの自動設計に関する検討を行う予定 である。

(平成 19 年 3 月 6 日受付，平成 19 年 6 月 21 日再受付)

\section{文献}

（1）豊田幸弘・濱田裕之：「遮断導波管の中に円柱誘電体共振器を装荷 した带域フィルタ」, 信学論 C-I, Vol.J79-C-I, No.5, pp.145-147 (1996)

（2）栗井郁雄: 「内部構造をもったマイクロ波共振器」, 信学論 C, Vol.J85-C No.4, pp.217-226 (2002)

（3）橋本环万 ·平田勝弘 他 :「誘電体フィルタの特性解析」, 電学全大会 講演論文集, 1-176 (2003)

（4）東出祐樹・小林禧夫：「マイクロストリップ集中定数帯域通過フィ ル夕の設計方法の改善」, 信学技報, MW2002-163 (2003-1), pp.39-44 (2003-1)

（正員） 1969 年 12 月 23 日生。1992 年 3 月同志 社大学工学部電気工学科卒業。1994 年 3 月同大 学大学院工学研究科電気工学専攻修士課程修了。 同年松下電工（株）入社，技術研究所勤務。主と して電磁界解析，電磁アクチュエータ，電磁セン サ，トランスの研究開発に従事。
平 田 勝 弘 （上級会員） 1958 年 4 月 10 日生。1 982 年 3 月大

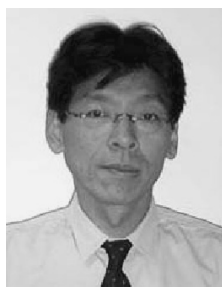
阪大学機械工学科卒業。同年 4 月松下電工 (株), 技術研究所勤務。2005 年大阪大学大学院工学研 究科・助教授を経て，2007 年同大教授，現在に 至る。主として電磁界解析, リニア電磁アクチュ エータ，電磁センサに関する研究に従事。工学博 士。2003 年文部科学大臣賞 (研究功績者) 受賞。 2004 年オーム技術賞受賞。IEEE 会員他。

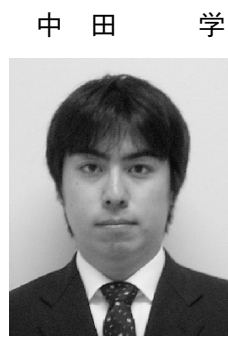

(正員) 1980 年 8 月 18 日生。 2003 年 3 月同志 社大学工学部電気工学科卒業。2005 年 3 月同大 学大学院工学研究科電気工学専攻修士課程修了。 同年松下電工（株）入社，技術研究所勤務。主と して電磁界解析，共振器結合形フィル夕，高周波 トランスの研究開発に従事。

石 原 好 之（正員） 1964 年同志社大·工・電気卒業。同年岡

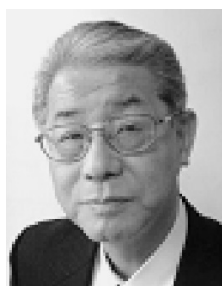
山大·工・助手，講師，助教授を経て，1981 年同 志社大助教授，1985 年同大教授，現在に至る。工 博。主として，電気機器鉄心の磁気特性に関する 研究及び太陽光発電システムに関する研究に従事。

戸 高 敏 之 (正員) 1961 年同志社大 ·工・電気卒業。1963 年

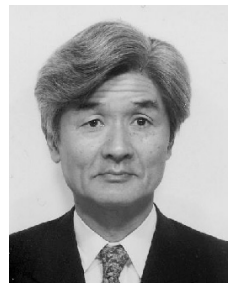
同大大学院工学研究科修士課程修了。同年同大 · 工・助手，1981 年同教授，現在に至る。工博。主 として，磁気応用に関する研究に従事。 